\title{
Measuring Customer Retention in the European Automotive Sector
}

\author{
Piotr Sliż ${ }^{1}$ Liwia Delińska²
}

Submitted: 25.05.2020. Accepted: 4.05.2021

\section{Abstract}

Purpose: The main purpose of the work is to present the results of the customer retention level in the automotive sector based on the proposed measurement indicators: "serviced and sold" (SESO) and "sold and serviced" (SOSE).

Design/methodology/approach: The study investigates the dealership of passenger cars belonging to one of the European automotive concerns. The following research methods were used in the article: systematic literature review, participant observation, and data mining.

Findings: As a result of the implementation of empirical proceedings, we proposed a theoretical model in terms of data flow in sales and aftersales service processes, thus enabling the design of SOSE and SESO retention indicators and their empirical verification in the examined organization.

Research limitations/implications: The presented indicators can be widely used in the analysis of retention of aftersales service clients. However, the presented research results cannot be applied to other organizations that provide similar results due to the non-probabilistically selected company.

Practical implications: The proposed indicators can be used by other organizations in different industries in assessing the level of retention in manufacturer-user and seller-user relations.

Originality/value: The study provides tools that allow for retention analysis from both the customer and product viewpoint. The concept has a universal value for enterprises that conduct sales and aftersales services under one structure.

Keywords: customer retention, customer satisfaction, relationship marketing, aftersales service, automotive.

$$
\text { JEL: M10, M30, M11, M31. }
$$

1 Gdansk University, Faculty of Management, 8 Bazynskiego St., Gdansk 80-952, Poland, e-mail: piotr.sliz@ug.edu.pl; https://orcid.org/00000001-6776-3369.

2 Corresponding author, Gdansk University, Faculty of Management, 8 Bazynskiego St., Gdansk 80-952, Poland, e-mail: liwia.delinska@ ug.edu.pl; https://orcid.org/0000-0002-1183-6247. 


\section{Introduction}

The relationship between the functioning of modern organizations in a dynamic market environment is determined by satisfying the needs of buyers in line with their expectations. Undeniably, the most important entities for enterprises operating on the commercial market are customers identified as the main accelerators of changes in organizations (Saarijärvi et al., 2013). The degree to which organizations retain customers is called "retention" in the literature. It is of widespread interest among researchers in such areas of the economy as hotel industry (Adzoyi et al., 2018), banking (Darzi and Bhat, 2018), mobile telephony (Díaz, 2017), aviation services (Climis, 2016), medical tourism (Han and Hwang, 2018), retail (Julian et al., 2015), and e-commerce (Yen, 2015).

Customer retention is an imperative of the organization's competitiveness (Dal Bó et al., 2018) that has positive consequences for economic and financial development (Sun et al., 2007), which is an important goal of enterprises (Anderson et al., 2004). Each organization needs customers as the primary source of profit generation (Gupta and Zeithaml, 2006). According to the marketing orientation, what is crucial is a focus on clients and their needs, but also responding to all signals sent by customers (Kotler and Keller, 2015). Such actions enable organizations to achieve their goals more effectively than the competition. Retention rate is used to measure the effectiveness of actions that lead to repeated purchases made by customers (Kozielski, 2011).

The main axis of this article is the assessment of the level of retention of aftersales service customers at an authorized service station for premium passenger cars. Unlike other studies and research, the level of customer retention from services was verified based on two unique variables. The first one identified the customer (vehicle user) and the second one - the serial number (vehicle identification number, or VIN). This means that the data generated in the sales and aftersales services processes were explored and consolidated to find hidden dependencies and patterns enabling the assessment of customer retention.

The implementation of the main goal was assigned with partial goals that intertwine in the theoretical (TA) and empirical (TE) perspectives. TA1: The identification of the existing knowledge regarding the measurement of customer retention levels. TA2: The definition of customer retention on the example of aftersales services in automotive dealership. TE1: Presentation of proprietary indicators of the assessment result of the level of customer retention on the basis of consolidated data generated in sales and aftersales services processes. 


\section{Customer Retention: Research Gaps Identification}

\section{Bibliometric Analysis}

As a result of the theoretical study conducted using qualitative bibliometric analysis based on five databases (EBSCOhost, Emerald, Scopus, Springer, and the Web of Science), we identified a cognitive gap consisting of a small number of publications on the retention of aftersales services. Table 1 presents the quantitative bibliometric analysis.

Table 1. Quantitative bibliometric study

\begin{tabular}{|c|c|c|c|c|c|}
\hline \multirow{2}{*}{ Base } & \multirow{2}{*}{ Query } & \multicolumn{2}{|c|}{ Number of all publications } & \multicolumn{2}{|c|}{$\begin{array}{l}\text { Number of publications } \\
\text { in the last five years }\end{array}$} \\
\hline & & All & Articles & All & Articles \\
\hline \multirow{2}{*}{ 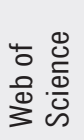 } & customer retention & 2179 & 1543 & 912 & 686 \\
\hline & $\begin{array}{l}\text { customer retention } \\
\text { aftersales }\end{array}$ & 11 & 7 & 4 & 2 \\
\hline \multirow{2}{*}{ 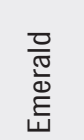 } & customer retention & 14851 & 13144 & 5218 & 4156 \\
\hline & $\begin{array}{l}\text { customer retention } \\
\text { aftersales }\end{array}$ & 565 & 489 & 134 & 186 \\
\hline \multirow{2}{*}{ 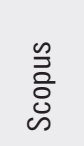 } & customer retention & 3174 & 2055 & 1008 & 669 \\
\hline & $\begin{array}{l}\text { customer retention } \\
\text { aftersales }\end{array}$ & 24 & 15 & 8 & 6 \\
\hline \multirow{2}{*}{$\begin{array}{l}\text { 오 } \\
\mathscr{N} \\
\text { ய }\end{array}$} & customer retention & 12649 & 3117 & 3007 & 821 \\
\hline & $\begin{array}{l}\text { customer retention } \\
\text { aftersales }\end{array}$ & 4 & 1 & 0 & 0 \\
\hline \multirow{2}{*}{ 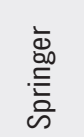 } & customer retention & 23996 & 7205 & 8257 & 2276 \\
\hline & $\begin{array}{l}\text { customer retention } \\
\text { aftersales }\end{array}$ & 909 & 181 & 257 & 47 \\
\hline
\end{tabular}

Source: own elaboration based on databases information.

The studied area of the aftersales service is defined in the literature as the main source of revenue, profit, and competitive advantage in most manufacturing industries (Cohen and Lee, 1990, Seth et al., 2005, Gaiardelli et al., 2007). In addition, the profits generated by the aftersales services are often higher than those obtained from sales. Therefore, organizations should focus management activities on monitoring aftersales service processes in the area of satisfaction measurement and customer retention analysis. 
Aftersales services reveal the needs and expectations of customers, which are the main indicator of retention and customer loyalty (Gallagher et al., 2005).

To clarify, aftersales services in the automotive sector are defined as "all activities geared towards maintaining the quality and reliability of the car conducted after the customer has taken delivery with the goal of ensuring customer satisfaction" (Omotuyi Ehinlanwo and Zairi, 1996, p. 44).

\section{Literature Review}

As part of the literature analysis, we reviewed the definitions of retention, which are included in Table 2. In a narrower perspective, customer retention is perceived by researchers as the retaining of buyers, i.e. continuing trade relations. In a broader sense, retention is also understood as the purchase intentions of buyers and their willingness to make recommendations to other customers. Therefore, we may distinguish an economic and behavioral approach to buyer retention.

From the perspective of an enterprise, retaining existing customers is definitely more profitable than investing large sums in acquiring new buyers (Weinstein, 2002; Seo et al., 2008). Moreover, even small increases in retention can lead to large increases in profits (Pfeifer and Farris, 2004). Therefore, customer retention has become a serious issue in the operations of enterprises and should be systematically analyzed so that internal conclusions and market activities adapted to them will help to retain current customers. Managers constantly seek ways to stimulate customer retention and increase their lifetime value (Rust et al., 2004). Customer retention was once described as a defensive marketing strategy (Fornell and Wernerfelt, 1987). Currently, it seems to be a consequence of building customer relationships.

Customer satisfaction is an important element of marketing orientation (Kotler and Armstrong, 2004) that affects the future purchasing behavior of customers (Yoo and Park, 2007). Customer satisfaction is perceived as the state in which the customer finds him/herself after the purchase, directly resulting from the customer's expectations of a given product, service, or shopping situation. Buyer satisfaction plays an important role in creating effective long-term customer relationships (Homburg and Rudolph, 2001). Ovenden (1995) proves that to retain consumers, they must be satisfied. Satisfied customers may become more committed to the service (Hennig-Thurau et al., 2002). As noted by Kumar et al. (2013), customer satisfaction only explains a small portion of loyalty variance and does not significantly increase customer retention 
(Kumar et al., 2013). Nevertheless, customer satisfaction is a necessary condition for keeping the consumer (Anderson and Mittal, 2000). This means that satisfaction is not the only and sufficient premise for customer retention, but it is essential.

Table 2. Definitions of retention in terms of selected authors

\begin{tabular}{|c|c|}
\hline $\begin{array}{c}\text { Author/Authors, Year, } \\
\text { Page }\end{array}$ & Definitions of the concept of "retention" \\
\hline $\begin{array}{l}\text { Alshurideh } \\
(2016, \text { p. 383) }\end{array}$ & $\begin{array}{l}\text { "all marketing plans and actions that seek to retain both existing and new } \\
\text { customers by establishing, maintaining, and maximizing mutual long-term } \\
\text { benefits that strengthen and extend the joint relationship between two } \\
\text { parties" }\end{array}$ \\
\hline $\begin{array}{l}\text { Steiner, Siems, Weber, } \\
\text { and Guhl (2014, p. 885) }\end{array}$ & $\begin{array}{l}\text { "customer retention on the one hand involves actual behavior such } \\
\text { as repeat buying and recommendations to others, while at the same time } \\
\text { it involves behavioral intentions in the form of planning to buy again (repeat } \\
\text { buying intention) or to buy additional products or services (cross-buying } \\
\text { intention), and intending to recommend a product or service to others" }\end{array}$ \\
\hline $\begin{array}{l}\text { Keiningham, Cooil, Aksoy, } \\
\text { Andreassen, and Weiner } \\
\text { (2007, p. 364) }\end{array}$ & "customers' stated continuation of a business relationship with the firm" \\
\hline $\begin{array}{l}\text { Ranaweera } \\
\text { and Prabhu } \\
(2003, \text { p. } 219)\end{array}$ & "the future propensity of the customers to stay with their service provider" \\
\hline $\begin{array}{l}\text { Stauss, Chojnacki, } \\
\text { Decker, and Hoffman } \\
\text { (2001, p. 15) }\end{array}$ & $\begin{array}{l}\text { "includes emotional-cognitive retention constructs (liking, identification, } \\
\text { commitment, trust) as well as behavioral intentions (willingness } \\
\text { to recommend and repurchase intention)" }\end{array}$ \\
\hline Oliver (1997, p. 392) & $\begin{array}{l}\text { "deeply held commitment to rebuy or repatronize a preferred product } \\
\text { or service consistently in the future, despite situational influences } \\
\text { and marketing efforts having the potential to cause switching behavior" }\end{array}$ \\
\hline
\end{tabular}

Source: own elaboration.

As part of the research conducted so far in the automotive sector, studies observe a positive relationship between customer satisfaction and willingness to cooperate (responsiveness), operation speed, services cost, and aftersales services quality (Fard and Hosseini, 2015). Moreover, in services, the immediate consideration of complaints positively influences customer satisfaction and increases brand credibility (Shams et al., 2020).

We should deliberately distinguish between customer loyalty and retention. In the absence of both economic and mental attachment, retention does not mean loyalty (Morgan et al., 2000). Disloyal customers will be less likely to absorb price increases 
or recommend services to others. However, we should emphasize that the main difference between loyalty and retention is the fact that loyalty primarily refers to a psychological predisposition for a repurchase, while retention means the actual repurchase (Johnson et al., 1997). Brand loyalty also means a positive customer attitude toward the brand or its offer (Rather, 2017). Behavioral loyalty intent refers to the subjective likelihood of the customer using the service again and the willingness to recommend it (Rather and Hollebeek, 2019). Researchers disagree regarding the key loyalty factors, which vary depending on the context (Rather and Sharma, 2016). Some (Martinez and Rodriguez del Bosque, 2014) consider social exchange-related factors to be crucial (e.g. customer trust, commitment), while others (Huang et al., 2017) position here social identification-related factors (e.g. customer brand identification). The direct predictors of customer behavioral intention of loyalty are affective commitment, customer satisfaction, and brand trust (Rather et al., 2019).

An important area of customer retention is relationship marketing, whose main goal is to develop and maintain mutually profitable and long-term customer relationships (Küster and Vila, 2006). Building and maintaining relationships with customers is particularly important when providing services by enterprises (Brodie, 2017). One definition describes relationship marketing as "attracting, developing, and retaining customer relationships" (Berry and Parasuraman, 1991, p. 133) Gaining a satisfied customer base is a widely recognized part of relationship marketing (Rather, 2018). Relationship strategy is recognized as a way to improve performance measures, including customer satisfaction, retention, and loyalty (Christopher et al., 2002). Employees' ability to listen to customer inquiries and positively respond to their needs and complaints is needed to establish a credible relationship with buyers on the aftersales market in the automotive industry (Izogo, 2015).

\section{Material and Methods}

We selected the automotive sector for this study due to the specificity of sales and aftersales services. From the perspective of car manufacturers, spare parts manufacturers, and authorized dealerships, the automotive sector is experiencing a reduction in profit resulting from the products' extended lifespan, which motivates the focus on aftersales services (Aboltins and Rivza, 2014). Many automotive companies achieve aftersales profits several times higher than those generated from the sale of new and used cars (Godlevskaja et al., 2011). The methodological framework of our empirical proceedings was constructed based on the assumptions of the cross-industry standard process for data mining (CRISP-DM) methodology. 
Empirical proceedings were conducted with the observation method. The study units were chosen in nonprobability sampling. The selection was determined by such parameters as the location of the organization, the implementation of sales processes and aftersales services under one franchise, and the classification of the organization on the third level of process maturity. We preliminarily selected three units for the proceedings, in which we conducted pilot studies related to the qualitative assessment of databases and activities measurement systems in the described processes. Following scholarship, we assumed that "it is widely recognized that a high-quality data warehouse is a necessary condition of successful mining" (Clifton and Thuraisingham, 2001). From the three organizations included in the design phase of the study, the one with the highest quality of data was selected. Data quality was evaluated by an interview with representatives of the organization, considering the ease of access, understanding, and use (Burns et al., 2000).

Authorized car dealership in Poland was qualified for the study. The entity sells maintenance services for two brands of premium passenger cars belonging to one group. During the survey, 30 employees were employed in the organization in three functional areas: new and used car sales department, service department, and parts and accessories department. Moreover, an assessment of the level of process maturity was conducted in 2017 in this organization following the Multicriteria Model of Process Maturity Assessment (MMPM) methodology (Sliż, 2018).

The empirical proceeding described in this article was implemented in 2018-2019 and is part of a broader research project. The analyzed unit sells and services two car brands belonging to one European automotive concern. Product sales and aftersales customer services were included in the main processes conducted in the analyzed organization.

The results presented in the study were based on a complete database from 2013-2018, which gathered 851 sales transactions of brand $x_{1}$ and $x_{2}$, and 2922 completed service interventions (completed repairs). The characteristics of variables are presented in Table 3.

The variables used in the analysis of the level of customer retention were subjected to data mining based on the product sales base and the aftersales service base. For the purposes of this study, a relational database was created marked as retention (see Figure 1). 
Table 3. Characteristics of the variables used in the retention database

\begin{tabular}{|c|c|c|c|}
\hline No. & $\begin{array}{l}\text { Variable / } \\
\text { attribute }\end{array}$ & Class & Variable characteristic \\
\hline 1 & sales__ VIN & [character, 17 signs] & $\begin{array}{l}\text { Unique vehicle variable - vehicle } \\
\text { identification number (VIN). }\end{array}$ \\
\hline 2 & sales_date & [date, format = $\left.{ }^{\circ} \% \mathrm{Y}-\% \mathrm{~m}-\% \mathrm{~d}\right]$ & The date the vehicle was sold to the customer. \\
\hline 3 & sales_brand* & [character] & $\begin{array}{l}\text { Variable assuming the values } x_{1} \text { for brand } 1 \\
\text { and } x_{2} \text { for brand } 2 \text {. }\end{array}$ \\
\hline 4 & order_type & [character] & Type of repair order. \\
\hline 5 & car_owner & [character] & Vehicle user data. \\
\hline 6 & invoide _ date & [date, format $=$ “\%Y-\%m-\%d] & $\begin{array}{l}\text { The sales document after the completed } \\
\text { repair. }\end{array}$ \\
\hline
\end{tabular}

* Only brands offered in accordance with the genotypic authorization of the analyzed unit were included in the analysis and construction of databases.

Source: own elaboration based on the study conducted in 2018-2019.

\section{Retention Rates Characteristics}

Based on the literature review and the exploration of the data obtained in the study, we proposed two indicators: serviced and sold (SESO) and sold and serviced (SOSE).

Depending on the adopted perspective, the first SESO indicator determines the share of customers who bought a car $\left(\mathrm{SESO}_{\mathrm{CuS}}\right)$ or products sold in the analyzed unit in the serial number (VIN) aftersales intervention database $\left(\mathrm{SESO}_{\mathrm{VIN}}\right.$; Record 1):

$$
C=\mathrm{A} \cap \mathrm{B}=\{x: x \in \mathrm{A} \wedge x \in \mathrm{B}\} \text { Record (1), }
$$

in which:

$A$ - set (database) of sales

$B$ - set (database) of after_sales

$\mathrm{C}$ - common set of sets A and B

$x$ - elements of variables car_owner $\left(\mathrm{SESO}_{\mathrm{CUS}}\right)$ or sales_VIN $\left(\mathrm{SESO}_{\mathrm{SN}}\right)$

The second SOSE indicator was expressed as the percentage share of product sold in the analyzed organization subjected subsequently to service intervention in the analyzed unit (SOSE $\mathrm{VIN}_{\mathrm{N}}$; $\mathrm{SOSE}_{\mathrm{CUS}}$; Record 2): 


$$
\mathrm{D}=\mathrm{B} \cap \mathrm{A}=\{x: x \in \mathrm{B} \wedge x \in \mathrm{A}\} \text { Record (2) }
$$

in which:

$A$ - set (database) of sales

$B$ - set (database) of after_sales

$\mathrm{D}$ - common set of sets B and A

$x$ - elements of variables car_owner ( $\left.\mathrm{SOSE}_{\mathrm{CUS}}\right)$ or sales_VIN $\left(\mathrm{SOSE}_{\mathrm{VIN}}\right)$

Documentation analysis and the use of the Delphi method with automotive market experts showed that the SOSE indicator must be presented in partial form, considering the types of interventions determined by the type of repair orders implemented (order type variable). The characteristics of the types of repairs are presented in Table 4.

Table 4. Characteristics of repairs types (types of repair orders) conducted in the analyzed unit

\begin{tabular}{|l|l|}
\hline \multicolumn{1}{|c|}{ Repair type } \\
\begin{tabular}{|l|} 
Repair \\
order type
\end{tabular} & \multicolumn{1}{c|}{ Characteristics } \\
\hline Body & $\begin{array}{l}\text { Body and paint orders conducted for external clients (individual clients, } \\
\text { insurance and internal companies, new and used car sales department). }\end{array}$ \\
\hline Internal & Internal orders conducted for an internal customer. \\
\hline Normal & Paid orders conducted for external customers. \\
\hline Salon & Orders (e.g. additional fitting of a new vehicle, pre-delivery inspection). \\
\hline Warranty & $\begin{array}{l}\text { Warranty orders conducted for external customers but settled with the } \\
\text { warranty department of the importer or car manufacturer. }\end{array}$ \\
\hline
\end{tabular}

Source: own elaboration of the research conducted in 2018-2019.

A factor in favor of our approach was the fact that the vast majority ( $>96 \%)$ of cars sold in the analyzed unit must be subjected to pre-delivery inspection. This means that the total value of the SOSE indicator may be disturbed by the implementation of the first service. For this purpose, the SOSE indicator has been considered partially, depending on the type of repair (type of order).

Figure 1 shows the data flow used in the analysis of SESO and SOSE retention rates. 
Figure 1. Data flow and characteristics in sales and aftersales service processes used in the design of SESO and SOSE indicators

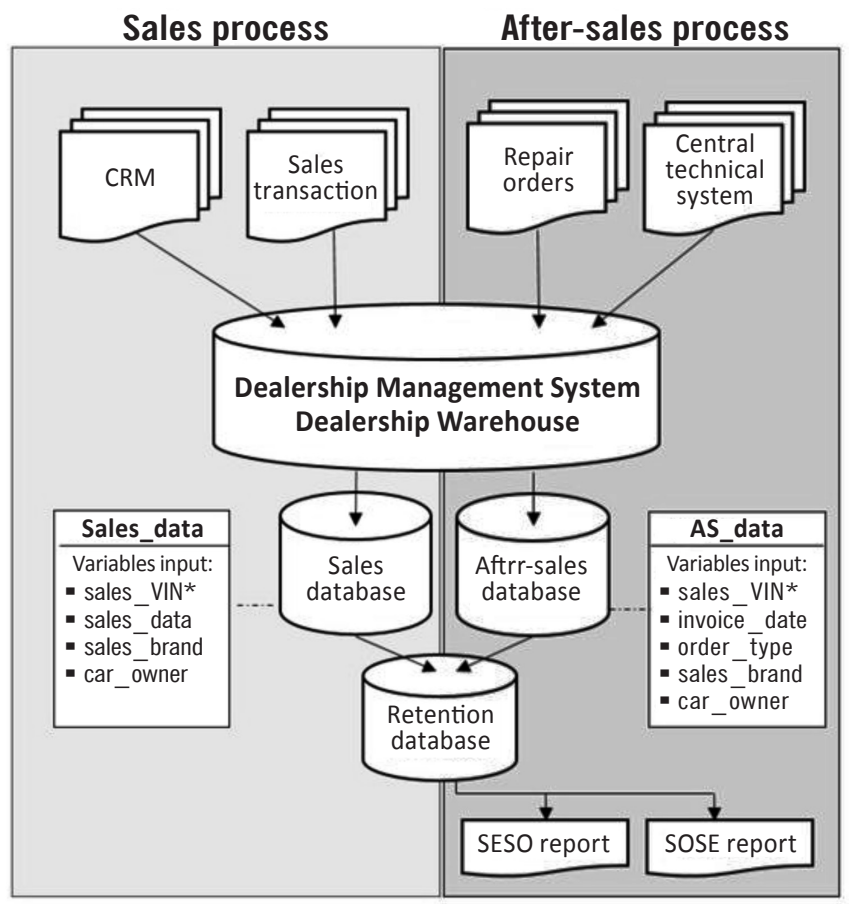

Source: own elaboration based on the research conducted in 2018-2019.

First, the number of unique records for the car_owner and sales_VIN variables was extracted from the sales and aftersales databases. The purpose of this action was to first identify the percentage structure of the share of customers who purchased a minimum of one car in the analyzed dealership and used aftersales services, and in the second approach, cars (products) that were subjected to aftersales service and sold in the analyzed unit.

\section{Results and Discussion}

\section{Results from the Product Perspective (sales_VIN variable)}

Based on the data analysis, the following results were obtained for 2018: $\mathrm{SESO}_{\mathrm{VINx} 1}=$ 0.261 , while $\mathrm{SESO}_{\mathrm{VINx} 2}=0.312$. In turn, the values of the SOSE indicators in the analyzed organization and period for 2018 were as follows: $\mathrm{SOSE}_{\mathrm{VINx} 1}=0.959$ and SOSE$\mathrm{VIN} x 2_{2}=0.974$. Please note that the high value of the SOSE indicator is determined by the types of salon and internal repairs. 
Table 5 shows the breakdown by type of repair order and tested indicator. All types of repair orders were included in the analysis of retention results from the vehicle perspective.

Table 5. Summary of SESO and SOSE indicators in 2018 in the examined organization

\begin{tabular}{|l|l|l|l|l|}
\hline Indicator & \multicolumn{3}{|c|}{ SESO } & \multicolumn{2}{c|}{ SOSE } \\
\hline Brand & VINx1 & VINx2 & VINx1 & VINx2 \\
\hline Body & 0.325 & 0.406 & 0.221 & 0.257 \\
\hline Internal & 0.684 & 0.764 & 0.133 & 0.050 \\
\hline Normal & 0.201 & 0.239 & 0.595 & 0.605 \\
\hline Salon & 0.871 & 0.939 & 0.938 & 0.932 \\
\hline Warranty & 0.421 & 0.428 & 0.692 & 0.813 \\
\hline
\end{tabular}

Source: own elaboration of the research conducted in 2018-2019.

Next, the SOSE indicator values were summarized considering the year of vehicle use (see Figure 2).

Figure 2. Summary of the SOSE in 2013-2018 in the studied organization

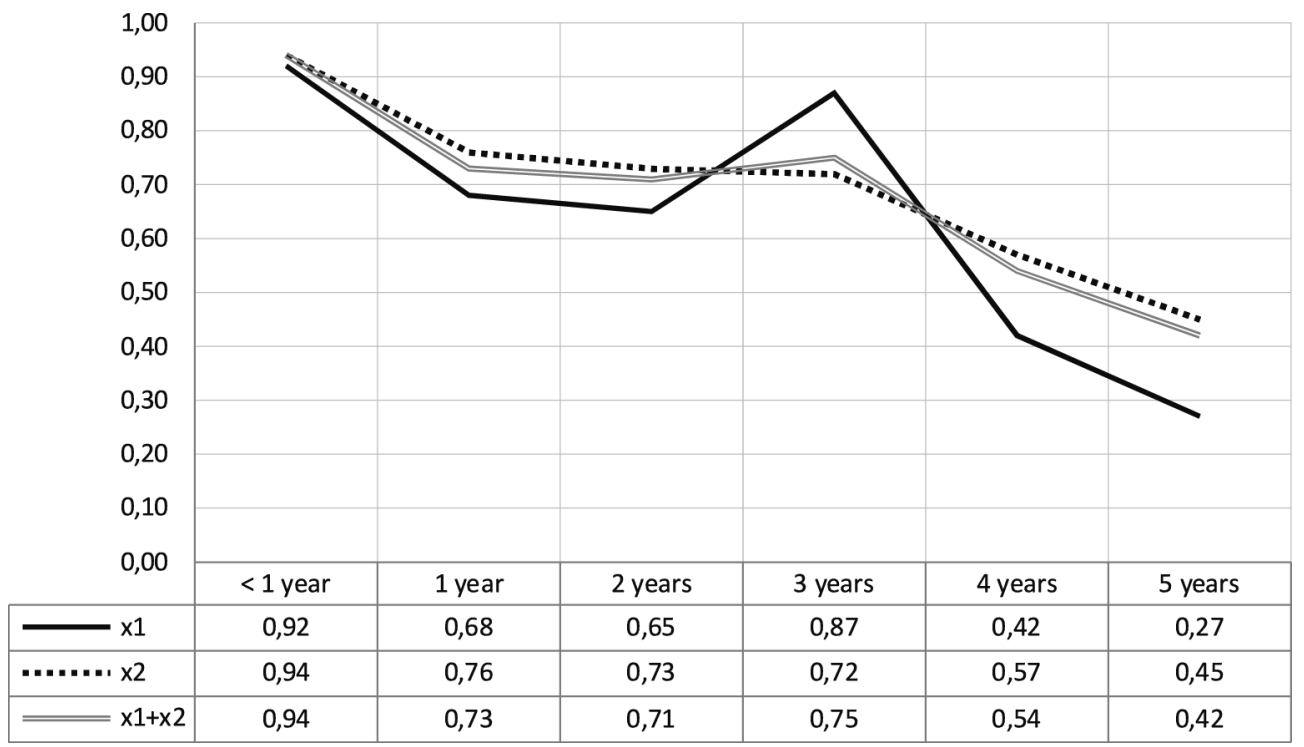

Source: own elaboration of the research conducted in 2018-2019. 
In the course of the study, the Delphi method was used with three experts working in sales, aftersales, and warranty service in the automotive sector. The method was implemented in the form of unstructured interviews, during which experts were asked to present the characteristics of the processes: sales of new cars, service, and warranty service. In addition, the obtained results were discussed in detail in a group of experts who, based on their knowledge and experience, identified the causes related to the technological aspects of car design and maintenance that may have a significant impact on the retention level. They indicated that the increase in the retention level for brand $\mathrm{x}_{1}$ in its third year of use is determined by the terms of the manufacturer's warranty, which specifies what types of defects can be repaired at the manufacturer's cost by this year of use. Up to the third year of exploitation (the time between reporting a fault and the date of purchase of the new vehicle), the scope of repairs is the widest and applies primarily to the replacement of parts defined in later years as operational wear (elements of the braking system, suspension, steering system, etc.). What is noteworthy is the approximate total value of the retention level for both brands. In this case, the warranty restrictions do not apply as they do for brand $\mathrm{x}_{1}$. It means that the increase in the retention level for both brands is primarily determined by the value of the SOSE indicator for brand $\mathrm{x}_{1}$.

The formulated conclusions prompted us to partially assess the level of retention by considering three types of repairs. Figures 3-4 present the analysis of the SOSE indicator level for 2018, taking into account the two brands examined separately ( $\mathrm{x}_{1}$ and $\mathrm{x}_{2}$ ) and including repair order type (body, normal, and warranty).

In Figure 3, the curve that shows the level of retention rate for $\mathrm{x}_{1}$ warranty repairs confirmed the previous thesis regarding the decrease in the level of customer retention after three years for warranty repairs. This is due to the removal of defects in the first two years of use and the reduced number of service actions. Moreover, a very strong SOSE increase was also noticed between two and three years of exploitation for repairs defined as normal. It is related to the warranty policy and the need to conduct a car service inspection. We should indicate that in most sold and serviced cars, the first three inspections are free for an external customer, which visibly increases the level of retention in the tested car brand. At this point, let us highlight that for lines $\mathrm{x}_{1}$ normal and $x_{1}$ warranty, we notice a visible decrease in the retention level between three and four years of exploitation. This condition may also result from the fact that users sell a car that is no longer serviced by the next owner at an authorized station or due to a change in location, meaning that it receives service at another vehicle station. To confirm the thesis formulated in this way, we would have to assess the level of reten- 
tion from the perspective of the entire dealer network of the tested brands $\mathrm{x}_{1}$ and $\mathrm{x}_{2}$, which was impossible in the scope of this study.

Figure 3. Summary of the SOSE $E_{V I N}$ retention indicator in 2018 for the brand $x_{1}$ in 2013-2018 in the studied organization

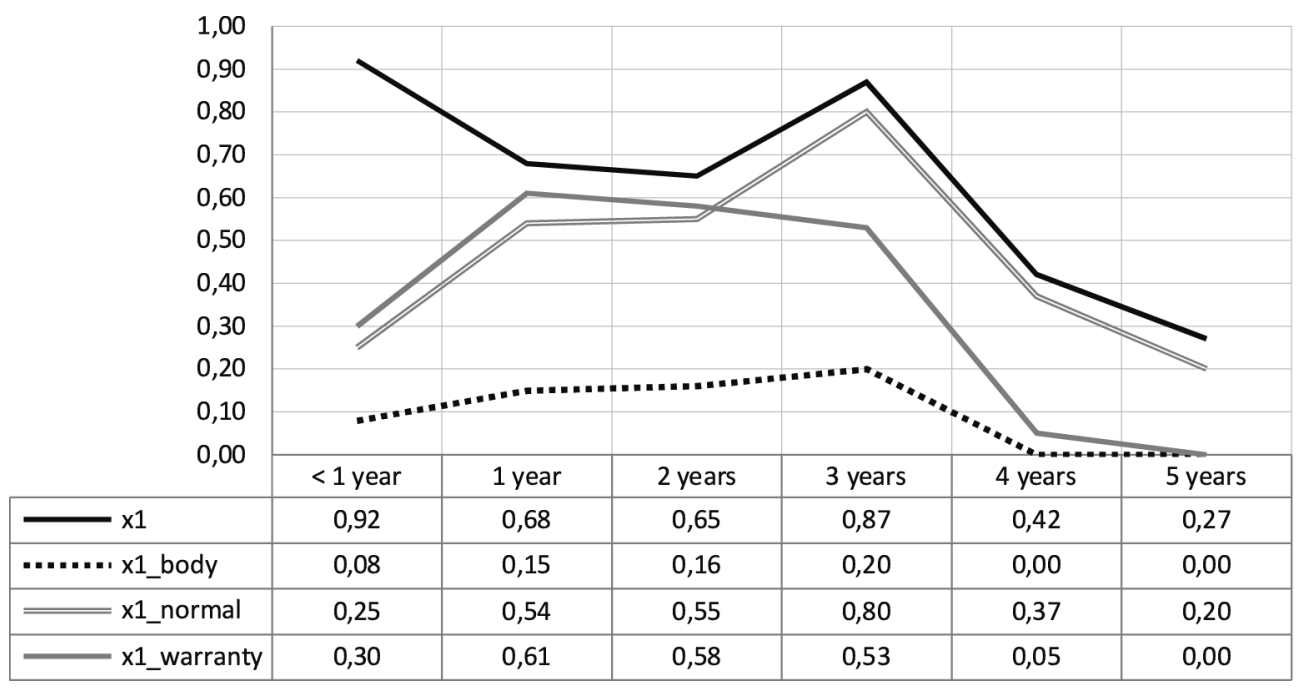

Source: own elaboration of the research conducted in 2018-2019.

Figure 4. Summary of the SOSE $E_{V I N}$ retention indicator in 2018 for the brand $x_{2}$ in 2013-2018 in the studied organization

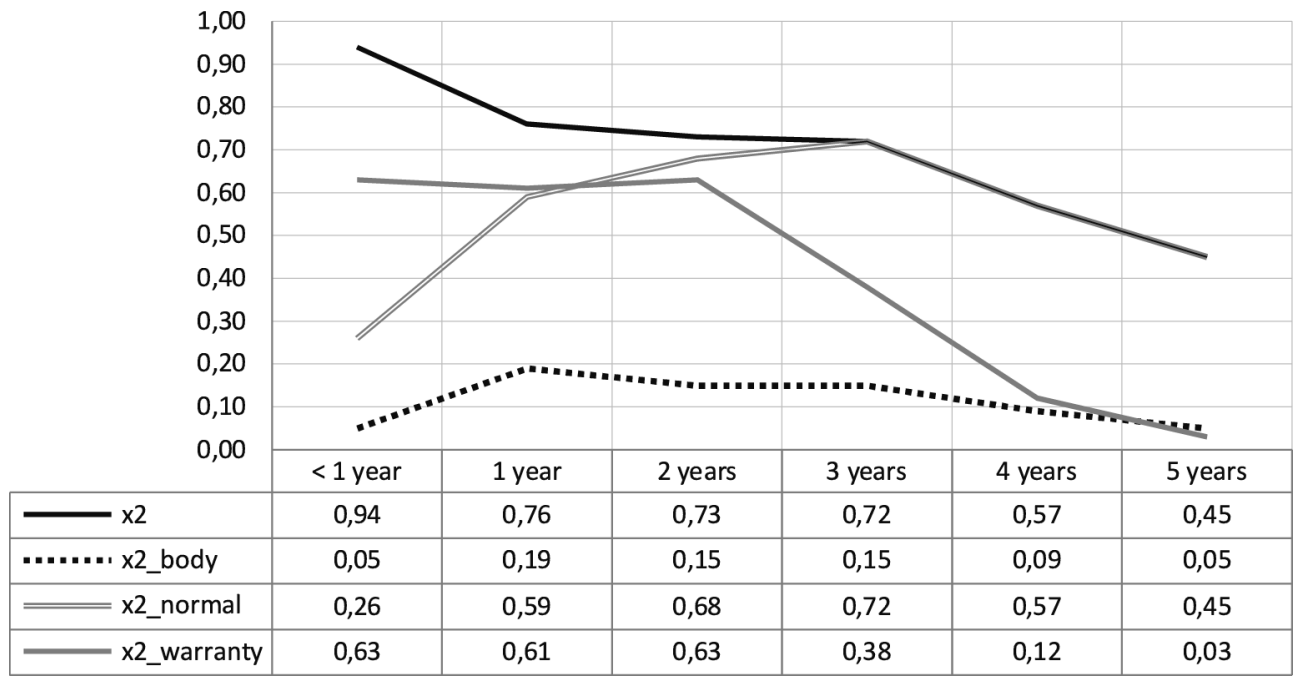

Source: own elaboration of the research conducted in 2018-2019. 
Figure 4 presents a partial summary of the SOSE indicator, including the types of repairs tested for brand $\mathrm{x}_{2}$. A detailed assessment of the data provided evidence that the retention level for all types of repairs decreases over the five-year product life period. Compared to brand $\mathrm{x}_{1}$, there is a noticeable difference in retention level for warranty repairs. In the described brand, the retention level does not decrease after three years of exploitation, but after two years, with a clear indication that the value of SOSE for both brands in the second year is similar: -0.65 and 0.73 , respectively for brand $x_{1}$ and brand $x_{2}$. The level of retention presented in Figure 4 was consulted with automotive market experts working at the authorized service station of the tested brands $\mathrm{x}_{1}$ and $\mathrm{x}_{2}$. The high level of retention for brand $\mathrm{x}_{2}$ was determined by the high defectiveness of cars produced in 2013-2014. This resulted from the launch of new models with construction and technological parameters that had not been used before. Second, the experts assessed that most of the faults were revealed in the first two years of vehicle exploitation. Such a conclusion was based on the analysis of the number of manufacturer's service actions implemented as warranty repairs, which directly influenced the level of retention for this type of repair.

\section{Results from the Customer Perspective (car_owner variable)}

As a result of the customer analysis conducted in the studied unit in 2013-2018, we estimated the SESO and SOSE indicators. The summary results are as follows: SES$\mathrm{O}_{\mathrm{CUSx} 1}=0.131$, while $\mathrm{SESO}_{\mathrm{CUSx} 2}=0.189$, $\mathrm{SOSE}_{\mathrm{CUS} x 1}=0.444$ and $\mathrm{SOSE}_{\mathrm{CUSx} 2}=0.582$.

Figure 5 presents a summary of the total value of the $\mathrm{SOSE}_{\mathrm{CUS}}$ indicator for brands $\mathrm{x}_{1}$ and $\mathrm{x}_{2}$ separately and for both brands simultaneously.

Comparing the results of the SOSE indicator from the customer perspective and the product perspective, we noticed differences between the data presented in Figures 2 and 5. First, the difference in retention level below one year of exploitation is mainly caused by the implementation of activities related to the preparation of the vehicle for sale. According to the manufacturer's conditions, in the vast majority of cases, a pre-delivery inspection must be conducted prior to sale. This explains the approximation of the SOSE indicator for this period to almost the maximum value. Second, the aggregated level of retention (without division into types of repairs) for brands $\mathrm{x}_{1}$ and $\mathrm{x}_{2}$ indicates very similar results, which may mean that customers of brand $\mathrm{x}_{1}$ are vehicle owners for a much longer time than in the case of brand $x_{2}$. Third, contrary to the SOSE value from the product perspective (Figure 2), we did not notice such a strong impact of the SOSE value for brand $x_{2}$ on the total level of customer retention. 
Figure 5. Summary of the SOSE $\mathrm{CuS}_{\text {r }}$ retention index in 2018 for the brands $x_{1}$ and $x_{2}$ including the years of vehicle use

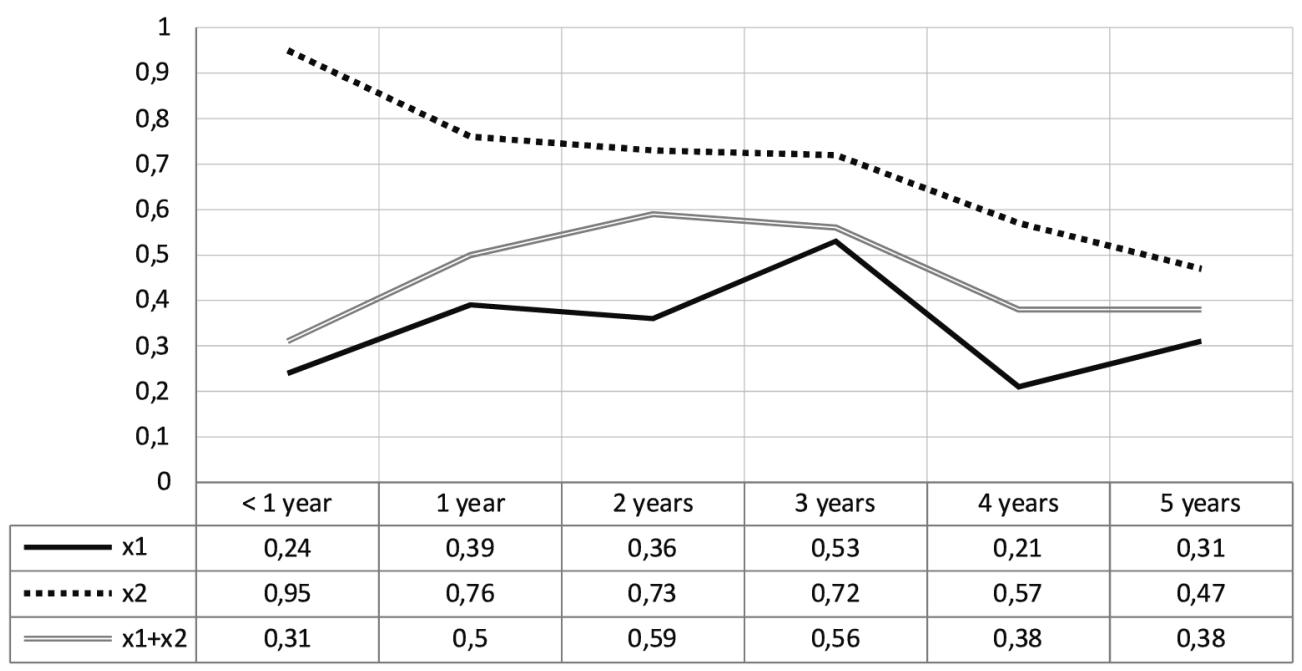

Source: own elaboration of the research conducted in 2018-2019.

Subsequently, as in the previous section of the article, the analysis of the SOSE indicator began with the aggregate values for brands $\mathrm{x}_{1}$ and $\mathrm{x}_{2}$. Detailed results for types of body and normal orders are presented in Table 6.

Table 6. Summary of SESO and SOSE indicators for 2013-2018 in the studied organization

\begin{tabular}{|l|l|l|l|l|}
\hline \multicolumn{1}{|c|}{ Indicator } & \multicolumn{2}{|c|}{ SESO $_{\text {cus }}$} & \multicolumn{2}{c|}{ SOSE } \\
\hline Brand & $\mathrm{VINx}_{1}$ & $\mathrm{VINx}_{2}$ & $\mathrm{VINx}_{1}$ & $\mathrm{VINx}_{2}$ \\
\hline Body & 0.294 & 0.350 & 0.200 & 0.251 \\
\hline Normal & 0.119 & 0.190 & 0.378 & 0.565 \\
\hline
\end{tabular}

Source: own elaboration of the research conducted in 2018-2019.

In this part of the study, only paid (normal), body, and paint (body) orders were included because we believed that their implementation is determined by the choice of an authorized service station by the customer and the fact that the other types of orders (warranty, salon, and internal) have one agreed intervention payer.

Figures 6-7 summarize the analysis of the SOSE indicator level for two brands examined separately $\left(\mathrm{x}_{1}\right.$ and $\left.\mathrm{x}_{2}\right)$, considering the vehicle owner and the vehicle itself and including repair order type (body, normal) for both. 
Figure 6. Summary of the $\mathrm{SOSE}_{\mathrm{CuS}}$ retention indicator in 2018 for the brand $\mathrm{x}_{1}$ taking into account the years of use of the vehicle and division of the repair order into types

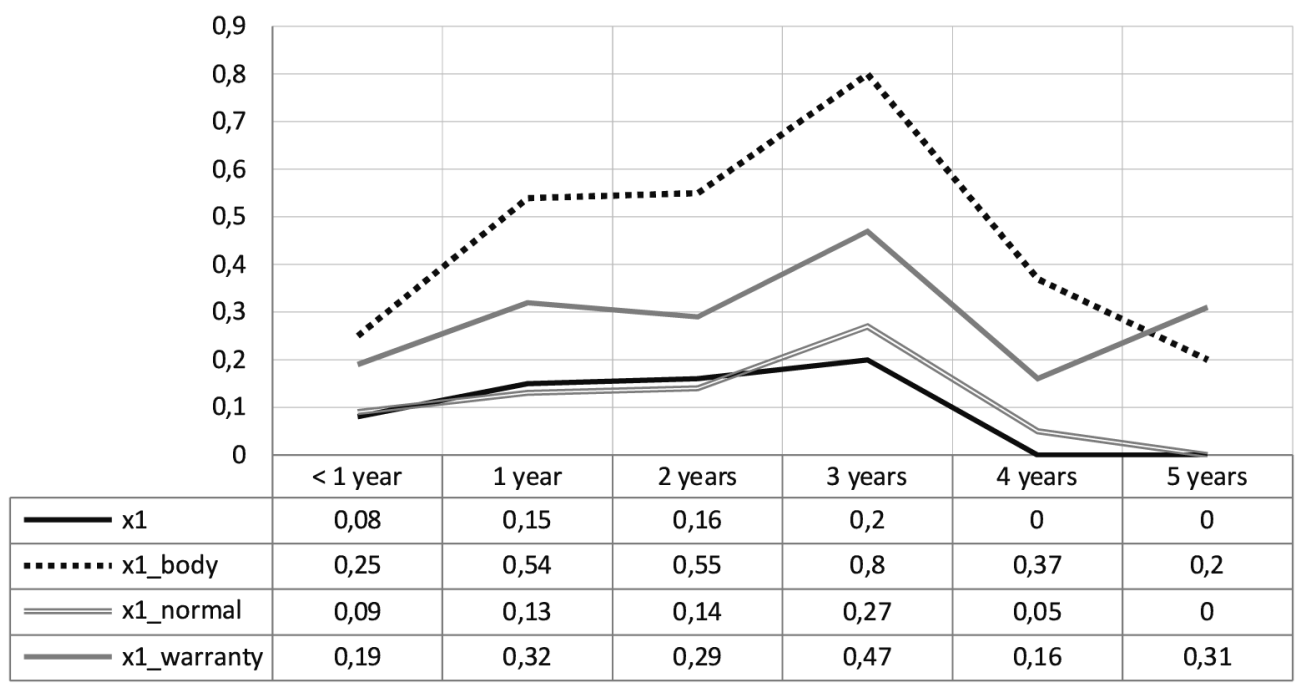

Source: own elaboration of the research conducted in 2018-2019.

Figure 7. Summary of the $\mathrm{SOSE}_{\text {cus }}$ retention index in 2018 for the brand $x_{2}$ taking into account the years of vehicle use and division into the repair order types

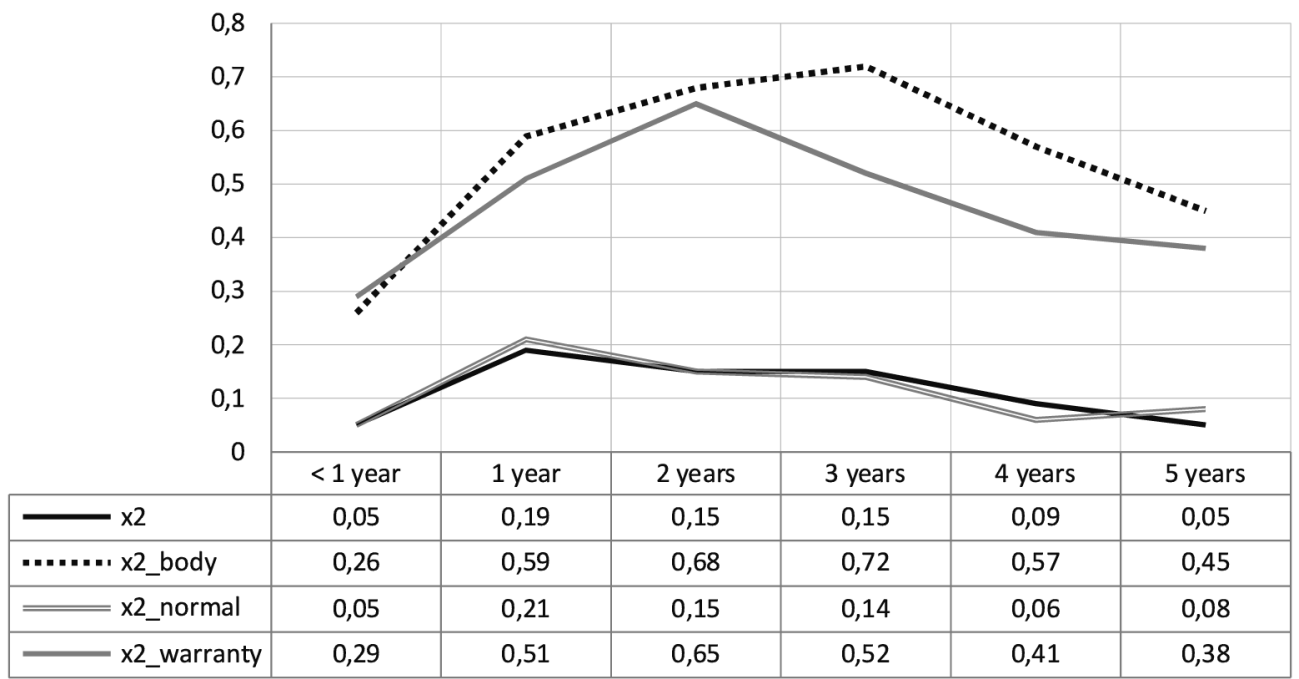

Source: own elaboration of the research conducted in 2018-2019.

Comparing the values of the tested retention level indicator in Figures 3 and 6, we noticed a similarity. Focusing on the analysis of Figure 6, pay attention to the x1_nor- 
mal_owner line, which indicates the cyclicality of the increase in the retention level every two years: one, three, and five years of exploitation. The line is directly related to the time of implementation of vehicle inspections. As in Figure 3, there is a noticeable increase in retention levels in the third year of vehicle use. The reasons for this state are concurrent with the conclusions formulated above. The assessment of the retention level from the product owner perspective - in this case the vehicle user also provided evidence that the retention level is additionally determined by the leasing period and the package of free inspections in the first three years.

As we can see in Figure 7, the level of retention by type of repair for brand $x_{2}$ from the customer perspective is also determined by the leasing period.

\section{Conclusion}

Following the implementation of empirical proceedings and based on data and documentation in the analyzed unit, we attempted to classify types of repairs and proposed a theoretical model in terms of data flow in sales and aftersales service processes, thus enabling the design of SOSE and SESO retention indicators and their empirical verification in the studied organization. Two separate indicators allow for the analysis of retention levels by considering strategic goals for vehicle sales processes and aftersales services sales processes. Figure 8 presents the value of the SOSE indicator as a function of years of car use, taking into account the customer perspective (SOSE $\mathrm{SUS}_{\text {S }}$ ) and product perspective $\left(\mathrm{SOSE}_{V I N}\right)$.

Moreover, let us emphasize that there are differences in the level of retention in relation to the product owner (owner) - i.e. taking into account the customer perspective - and in relation to the product itself (VIN), i.e. taking into account the product perspective. Based on the obtained results in the completed empirical study, we proved that there are significant differences from the perspective of formulating organization goals and strategy, differentiated in the assessment of the level of retention by the SESO and SOSE indicators for the same time series.

The above research results refer to a non-probabilistically selected enterprise, without the possibility of relating the obtained results to other organizations that provide similar services. This means that despite our access to the complete sales and aftersales service database, our conclusions apply only to the examined set of vehicles and aftersales services sold. However, we emphasize that the main purpose of the study was to present a universal concept for measuring the level of customer retention for 
companies that implement the process of sales and aftersales services under one structure. Thus, the SESO and SOSE indicators can be used by authorized car service stations, regardless of the supported vehicle brand or geographical location. In our opinion, the presented indicators and replication possibilities of this study can be used not only in the automotive sector but also in other industries, such as agriculture, automatics, aviation, or construction machinery.

Figure 8. Summary of the SOSE $E_{V I N}$ and SOSE $E_{C U S}$ retention rates in 2018 for the brands $x_{1}$ and $x_{2}$ in 2013-2018 in the studied organization

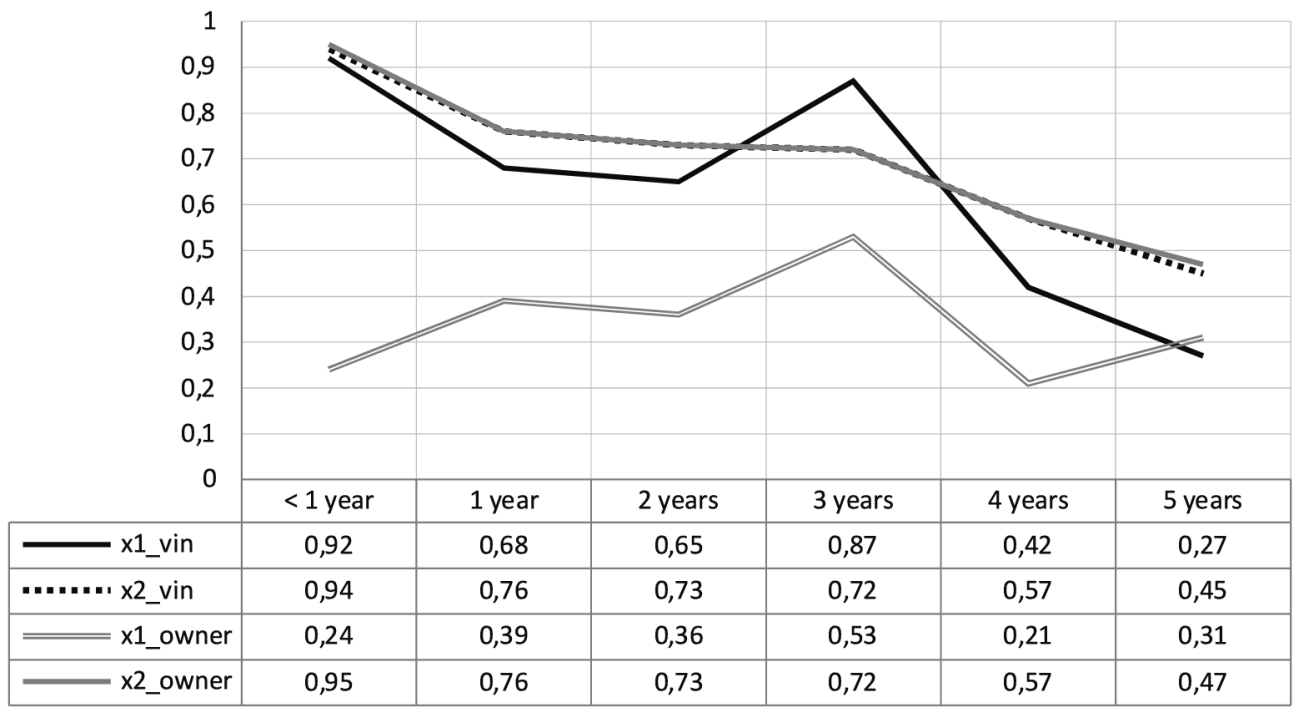

Source: own elaboration of the research conducted in 2018-2019.

The presented concept of measuring the level of retention with the use of SOSE and SESO indicator emphasizes the need to test retention by considering customers who purchase the products and their users. Such a division constitutes an additional voice in the discussion on retention studies, with the clear assumption that the analysis of both indicators requires a detailed registration of data on customers and users of products. Moreover, from the perspective of the studied issue and the use of the discussed indicators, we must know the specifics of analyzed sectors or organizations so as to correctly describe changes in retention levels, but also to correctly identify their causes, which in the discussed case, focus on technological reasons. This means that the interpretation of obtained results should be conducted in an interdisciplinary team. 


\section{Practical Application}

The aftersales services marked in the automotive industry undergoes transformations as an important aspect of business operations becomes retaining customers of aftersales services, which constitute a key part of profits. The challenge for the aftersales relationship marketing are changes determined by the increase in the number of customers who consume a product without ownership (Moeller and Wittkowski, 2010), identified in the literature as the non-ownership mentality (Godlevskaja et al., 2011). Therefore, enterprises should adapt their customer retention strategy to market trends.

Therefore, when analyzing current trends in the market environment of modern organizations, management and marketing activities should focus on adapting customer retention programs to the expectations structure of car users, with particular emphasis on aftersales services, regardless of the form of ownership. Therefore, it seems reasonable to monitor the level of retention by considering the indicators proposed in our article. This means that when assessing the level of customer retention in the study area, we should consider both measurement perspectives: that of the customer and that of the vehicle identification number. The observed change is the approach to vehicle ownership, which implies businesses in relationship marketing.

The research we conducted has several practical contributions. First, the proposed indicators allow a horizontal view of customer retention in a plethora of industries, as the indicators can be used both from the perspective of the sales process and the aftersales service. Second, we showed on the example of the automotive sector that it is worthwhile to analyze customer retention from both customer and product viewpoints, as they may give different results in a time series. Third, the analysis of the level of retention using the proposed indicators should be a premise for creating relationship programs in a company by adapting to the level of retention in the year of product use.

The presented concept of retention measurement is applicable not only in the automotive sector but also in other sectors that implement sales, aftersales, and warranty processes.

\section{Limitations and Future Research}

The barriers in the application of our concept of measuring retention mainly concern the limited access to data that organizations treat as confidential. On the other hand, from the perspective of management - both in the automotive and other sectors - in 
which the proposed SOSE and SESO indicators would be used, the main barrier is related to the integration of databases on sales, aftersales, and warranty service processes. At this point, we must underline the need to verify the quality of generated and explored data. Please note that the conclusions presented based on quantitative research are of a generalized nature and should be verified by empirical facts examined in qualitative research. We suggest that future research should measure the customer retention of randomly selected enterprises from an industry by using the proposed indicators so as to find certain market regularities.

\section{References}

Aboltins, K. and Rivza, B. (2014). The Car Aftersales Market Development Trends in the New Economy. Procedia - Social and Behavioral Sciences, 110, 341-352. https://doi.org/10.1016/j.sbspro.2013.12.878.

Adzoyi, P., Jan Blomme, R. and Honyenuga, B. (2018). Customer Retention among Hotels in an Emerging Market: An Employee-Based Perspective. Advances in Hospitality and Leisure, 14, 57-73. https://doi.org/10.1108/S1745-354220180000014004.

Alshurideh, M.T. (2016). Is Customer Retention Beneficial for Customers: A Conceptual Background. Journal of Research in Marketing, 5(3), 382-389. https://doi.org/10.17722/jorm.v5i3.126.

Anderson, E., Fornell, C., and Mazvancheryl, S. (2004). Customer Satisfaction and Shareholder Value. Journal of Marketing, 68(4), 172-185. https://doi.org/10.1509/jmkg.68.4.172.42723.

Anderson, E. and Mittal, V. (2000). Strengthening the satisfaction-profit-chain. Journal of Service Research, 3(2), 107-120. https://doi.org/10.1177/109467050032001.

Berry, L.L. and Parasuraman, A. (1991). Marketing services. New York: Free Press.

Brodie, R. (2017). Enhancing theory development in the domain of relationship marketing: How to avoid the danger of getting stuck in the middle. Journal of Services Marketing, 31(1), 20-23. https://doi.org/10.1108/JSM-05-2016-0179.

Burns, E. M., MacDonald, O., and Champaneri, A. (2000). Data quality assesment methodology: A framework. In: Joint Statistical Meetings - Section on Government Statistics, 334-337.

Chatura, R. and Andy, N. (2003). Some moderating effects on the service quality-customer retention link. International Journal of Operations \& Production Management, 23(2), 230-248. https://doi.org/10.1108/01443570310458474.

Christopher, M., Payne, A. and Ballantyne, D. (2002). Relationship marketing: creating stakeholder value. London: Butterworth-Heinemann.

Climis, R. (2016). Factors Affecting Customer Retention in the Airline Industry. Journal of Management and Business Administration. Central Europe, 24(4), 49-69.

https://doi.org/10.7206/jmba.ce.2450-7814.182.

Cohen, M.A. and Lee, H.L. (1990). Out of touch with customer needs? Spare parts and after sales service. MIT Sloan Management Review, 31(2), 55-66.

Dal Bó, G., Milan, G.S., and de Toni, D. (2018). Proposal and validation of a theoretical model of customer retention determinants in a service environment. RAUSP Management Journal, 53(2), 202-213. https://doi.org/10.1016/j.rauspm.2017.06.004. 
Darzi, M. and Bhat, S. (2018). Personnel capability and customer satisfaction as predictors of customer retention in the banking sector: A mediated-moderation study. International Journal of Bank Marketing, 36(4), 663-679. https://doi.org/10.1108/IJBM-04-2017-0074.

Díaz, G.R. (2017). The influence of satisfaction on customer retention in mobile phone market. Journal of Retailing and Consumer Services, 36, 75-85. https://doi.org/10.1016/j.jretconser.2017.01.003.

Fard, S.S. and Hosseini, S.M. (2015). Performance measurement of the aftersales service network: Evidence from the automotive industry. Management Science Letters, 5, 927-932. https://doi.org/10.5267/j.msl.2015.8.004.

Fornell, C. and Wernerfelt, B. (1987). Defensive marketing strategy by customer complaint management: A theoretical analysis. Journal of Marketing Research, 24(4), 337-346. https://doi.org/10.1177/002224378702400401.

Gaiardelli, P., Saccani, N. and Songini, L. (2007). Performance measurement of the aftersales service network - Evidence from the automotive industry. Computers in Industry, 58, 698-708. https:// doi.org/10.1016/j.compind.2007.05.008.

Gallagher, T., Mitchke, M.D. and Rogers, M.C. (2005). Profiting from spare parts. The McKinsey Quarterly, 2.

Godlevskaja, O., van Iwaarden, J. and van der Wiele, T. (2011). Moving from product-based to service-based business strategies: Services categorisation schemes for the automotive industry. International Journal of Quality \& Reliability Management, 28(1), 62-94. https://doi.org/10.1108/02656711111097553.

Gupta, S. and Zeithaml, V. (2006). Customer metrics and their impact on financial performance. Marketing Science, 25(6), 718-739. https://doi.org/10.1287/mksc.1060.0221.

Han, H. and Hwang, J. (2018). Growing competition in the healthcare tourism market and customer retention in medical clinics: New and experienced travelers. Current Issues in Tourism, 21(6), 680-702. https://doi.org/10.1080/13683500.2015.1104292.

Hennig-Thurau, T., Gwinner, K.P. and Gremler, D.D. (2002). Understanding relationship marketing outcomes: An integration of relational benefits and relationship quality. Journal of Service Research, 4(3), 230-247. https://doi.org/10.1177/1094670502004003006.

Homburg, C. and Rudolph, B. (2001). Customer satisfaction in industrial markets: dimensional and multiple role issues. Journal of Business Research, 52(1), 15-33. https://doi.org/10.1016/S01482963(99)00101-0.

Izogo, E.E. (2015). Customers' service quality perception in automotive repair. African Journal of Economic and Management Studies, 6(3), 272-288. https://doi.org/10.1108/AJEMS-02-2013-0024.

Johnson, M.D., Herrmann, A., Huber, F. and Gustafsson, A. (1997). An Introduction to Quality, Satisfaction, and Retention - Implications for the Automotive Industry. In: M.D. Johnson, A. Herrmann, F. Huber, and A. Gustafsson (eds.), Customer retention in the automotive industry: quality, satisfaction and loyalty, Gabler Verlag, Springer Fachmedien Wiesbaden GmbH, Wiesbaden, 1-17. https://doi.org/10.1007/978-3-322-84509-2_1.

Huang, M.H., Cheng, Z.H. and Chen, I.C. (2017). The importance of CSR in forming customer-company identification and long-term loyalty. Journal of Services Marketing, 31(1), 63-72. https://doi.org/10.1108/JSM-01-2016-0046.

Julian, C.C., Ahmed, Z.U., Che Wel, C.A. and Bojei, J. (2015). Discriminant Analysis of Antecedents of Customer Retention in Malaysian Retailing. Journal of Transnational Management, 20(3), 190-204. https://doi.org/10.1080/15475778.2015.1058694.

Keiningham, T., Cooil, B., Aksoy, L., Andreassen, T. and Weiner, J. (2007). The value of different customer satisfaction and loyalty metrics in predicting customer retention, recommendation, 
and share- of- wallet. Managing Service Quality: An International Journal, 17(4), 361-384. https://doi.org/10.1108/09604520710760526.

Kotler, P. and Armstrong, G. (2004). Principles of marketing. 10th edition. New Jersey: Pearson Pertinence Hall.

Kotler, P. and Keller, K.L. (2015). Marketing Management 14th Edition. Poznań: Rebis.

Kozielski, R. (2011). Wskaźniki marketingowe. Warszawa: Wolters Kluwer Polska.

Kumar, V., Pozza, I.D. and Ganesh, J. (2013). Revisiting the satisfaction-loyalty relationship: Empirical generalizations and directions for future research. Journal of Retailing, 89(3), 246-262.

Küster, I. and Vila, N. (2006). Relational strategies in the textile sector: Internet use. Journal of Relationship Marketing, 5(4), 3-22.

Martinez, P. and Rodriguez Del Bosque Rodriguez, I. (2014). Exploring the antecedents of hotel customer loyalty: a social identity perspective. Journal of Hospitality Marketing and Management, 24(1), 1-23.

Moeller, S. and Wittkowski, K. (2010). The burdens of ownership: reasons for preferring renting. Managing Service Quality: An International Journal, 20(2), 176-191. https://doi.org/10.1108/09604521011027598.

Morgan, R.M., Crutchfield, R.N. and Lacey, R. (2000). Patronage and Loyalty Strategies: Understanding the Behavioral and Attitudinal Outcomes of Customer Retention Programs. In: T. Hennig-Thurau, and U. Hansen (eds.), Relationship Marketing: Gaining Competitive Advantage Through Customer Satisfaction and Customer Retention. Berlin: Springer, 71-87. https://doi.org/10.1007/978-3-662-09745-8_5.

Oliver, R.L. (1997). Satisfaction: A Behavioral Perspective on the Consumer. New York: McGraw-Hill.

Omotuyi Ehinlanwo, O. and Zairi, M. (1996). Best practice in the car after - sales service: An empirical study of Ford, Toyota, Nissan and Fiat in Germany - Part II. Business Process Re-engineering $\&$ Management Journal, 2(3), 39-53. https://doi.org/10.1108/14637159610151208.

Ovenden, A. (1995). Keep your customers happy and your competition will slowly fade away. The TQM Magazine, 7(1), 46-49. https://doi.org/10.1108/09544789510076924.

Pfeifer, P.E. and Farris, P.W. (2004). The Elasticity of Customer Value to Retention: The Duration of a Customer Relationship. Journal of Interactive Marketing, 18(2), 20-31.

https://doi.org/10.1002/dir.20006.

Ranaweera, C. and Prabhu, J. (2003). The influence of satisfaction, trust and switching barriers on customer retention in a continuous purchasing setting. International Journal of Service Industry Management, 14(4), 374-395. https://doi.org/10.1108/09564230310489231.

Rather, R.A. (2018). Consequences of consumer engagement in service marketing: an empirical exploration. Journal of Global Marketing, 32(2), 116-135. https://doi.org/10.1080/08911762.2018.1454995.

Rather, R.A. (2017). Investigating the impact of customer Brand identification on hospitality Brand loyalty: a social identity perspective. Journal of Hospitality Marketing and Management, 27(5), 487-513. https://doi.org/10.1080/19368623.2018.1404539.

Rather, R.A. and Hollebeek, L. (2019). Exploring and validating social identification and social exchangebased drivers of hospitality customer loyalty. International Journal of Contemporary Hospitality Management, 31(3). https://doi.org/10.1108/IJCHM-10-2017-0627.

Rather, R.A. and Sharma, J. (2016). Brand loyalty with hospitality brands: the role of customer Brand identification, brand satisfaction and Brand commitment. Pacific Business Review International, 1(3), 76-86. 
Rather, R.A., Tehseen, S., Itoo, M.H. and Parrey, S.H. (2019). Customer brand identification, affective commitment, customer satisfaction, and brand trust as antecedents of customer behavioral intention of loyalty: An empirical study in the hospitality sector. Journal of Global Scholars of Marketing Science, 29(2), 196-217. https://doi.org/10.1080/21639159.2019.1577694.

Rust, R.T., Lemon, K.N. and Zeithaml, V.A. (2004). Return on marketing: using customer equity to focus marketing strategy. Journal of Marketing, 68(1), 109-127. https://doi.org/10.1509/jmkg.68.1.109.24030.

Saarijärvi, H., Kannan, P.K. and Kuusela, H. (2013). Value co-creation: theoretical approaches and practical implications. European Business Review, 25(1), 6-19. https://doi.org/10.1108/09555341311287718.

Seo, D., Ranganathan, C. and Babad, Y. (2008). Two-level model of customer retention in the US mobile telecommunications service market. Telecommunications Policy, 32, 182-196. https://doi.org/10.1016/j.telpol.2007.09.004.

Seth, N., Deshmukh, S.G. and Vrat, P. (2005). Service quality models: a review. International Journal of Quality \& Reliability Management, 22(9), 913-949. https://doi.org/10.1108/02656710510625211.

Shams, G., Rehman, M.A., Samad, S., and Rather, R.A. (2020). The impact of the magnitude of service failure and complaint handling on satisfaction and brand credibility in the banking industry. Journal of Financial Services Marketing, 25, 25-34. https://doi.org/10.1057/s41264-020-00070-0.

Sliż, P. (2018), Concept of the organization process maturity assessment. Journal of Economics \& Management, 33, 80-95. https://doi.org/10.22367/jem.2018.33.05.

Stauss, B., Chojnacki, K., Decker, A. and Hoffmann, F. (2001). Retention effects of a customer club. International Journal of Service Industry Management, 12(1), 7-19. https://doi.org/10.1108/09564230110382745.

Steiner, W.J., Siems, F.U., Weber, A. and Guhl, D. (2014). How customer satisfaction with respect to price and quality affects customer retention: an integrated approach considering nonlinear effects. Journal of Business Economics, 84, 879-912. https://doi.org/10.1007/s11573-013-0700-6.

Sun, B., Wilcox, R. and Zhu, T. (2007). Ignoring your best customer? An investigation of customer satisfaction, customer retention and their financial impact. Journal of Relationship Marketing, 6(3-4), 87-116. https://doi.org/10.1300/J366v06n03_05.

Weinstein, A. (2002). Customer retention: A usage segmentation and customer value approach. Journal of Targeting Measurement and Analysis for Marketing, 10(3), 259-268. https://doi.org/10.1057/palgrave.jt.5740051.

Yen, Y. (2015). Managing perceived risk for customer retention in e-commerce: The role of switching costs. Information and Computer Security, 23(2), 145-160. https://doi.org/10.1108/ICS-12-2013-0088.

Yoo, D.K. and Park, J.A. (2007). Perceived service quality - analyzing relationships among employees, customers and financial performance. International Journal of Quality and Reliability Management, 21(9), 908-926. https://doi.org/10.1108/02656710710826180. 